\title{
Zanthoxylum Piperitum Attenuates the Allergic Inflammation in vivo and in vitro
}

\author{
Duck-Ja Jeong ${ }^{1, *}$ and Su-Jin Kim ${ }^{2, \dagger ; *}$ \\ ${ }^{1}$ College of Korean Medicine, Daegu Haany University, Gyeongsan 38610, Korea \\ ${ }^{2}$ Department of Biotechnology and Convergence, Daegu Haany University, Gyeongsan 38610, Korea
}

\begin{abstract}
Natural products have received revived interest via traditional remedies or alternative medicine used for the treatment of various diseases. Zanthoxylum piperitum (ZP) has been utilized in traditional medicine for various medicinal purposes. The present study was conducted to evaluate whether ZP modulates allergic inflammation both in vivo and in vitro. We examined the pharmacological effects of ZP on 2, 4-dinitrochlorobenzene (DNCB)-induced atopic dermatitis (AD) symptoms in mice. Additionally, in order to clarify the anti-inflammatory mechanisms of ZP, we elucidate the effect of $\mathrm{ZP}$ on the expression levels of inflammatory cytokines and nuclear factor- $\mathrm{B}(\mathrm{NF}-\kappa \mathrm{B})$ in phorbol 12-myristate 13-acetate plus calcium ionophore A23187 (PMACI)-stimulated human mast cells (HMC-1). The results demonstrated that ZP attenuated $\mathrm{AD}$ clinical symptoms such as erythema, edema and dryness as well as histamine and IgE serum levels in DNCB-induced AD model mice. Additionally, ZP suppressed the expression of inflammatory cytokines and activation of NF- $\mathrm{BB}$ in $\mathrm{AD}$-like skin lesions and stimulated HMC-1. These results provide experimental evidence that ZP may be useful candidate for treating allergic inflammation including AD.
\end{abstract}

Key Words: Zanthoxylum piperitum; Allergic inflammation; Inflammatory cytokines; Nuclear factor- $\kappa B$; Mast cells

\section{INTRODUCTION}

Allergic inflammation plays a central role in allergic diseases and involves the action of multiple factors within a complex network (Hawiger, 2001). Recently, allergic inflammatory diseases have become a global health problem. Atopic dermatitis (AD), a chronic allergic inflammatory disease, is characterized by erythema, edema and severe pruritus (Waldman et al., 2018). Pathogenesis and progression of $\mathrm{AD}$ have been associated with a complex interrelationship between genetic, environmental, and immunologic factors as well as skin barrier dysfunction. Generally, AD is treated with corticosteroids (Berke et al., 2012), but long-term treatments can cause serious side effects such as immunosuppression and epidermal barrier dysfunction (Vatti et al., 2014). Consequently, there is a need to develop effective anti-atopic agents that cause fewer side effects.

Mast cells contribute to allergic inflammation, such as AD (Modena et al., 2016). Mast cells are important effector cells of IgE-mediated allergic inflammatory reactions and IgE levels are related to AD severity (Siraganian, 2003). In response to various stimuli, mast cells generate a variety of inflammatory cytokines including interleukin (IL)-6 and tumor necrosis factor (TNF)- $\alpha$ that contribute to the infiltration of immune cells to sites of inflammation (Trefzer et

Received: August 20, 2020 / Revised: September 9, 2020 / Accepted: September 10, 2020

* Professor.

${ }^{\dagger}$ Corresponding author: Su-Jin Kim. Department of Biotechnology and Convergence, Daegu Haany University, Gyeongsan 38610, Korea. Tel: +82-53-819-1389, Fax: +82-53-819-1389, e-mail: ksj1009@dhu.ac.kr

(C) The Korean Society for Biomedical Laboratory Sciences. All rights reserved.

(C) This is an Open Access article distributed under the terms of the Creative Commons Attribution Non-Commercial License (http://creativecommons.org/licenses/by-nc/3.0/) which permits unrestricted non-commercial use, distribution, and reproduction in any medium, provided the original work is properly cited. 
al., 2003). It was previously reported that mast cells are present in larger numbers in $\mathrm{AD}$ lesional skin. Therefore, the suppression of cytokine production by mast cells is a useful therapeutic strategy for allergic inflammation.

Nuclear factor-kappa B (NF- $\kappa$ B), transcription factor, regulates the transcription of numerous genes involved in allergic inflammation (Lee et al., 2020). Increased NF- $\mathrm{kB}$ activity associated with the secretion of high levels of IL-6 and TNF- $\alpha$ was shown to be involved in AD (Gilmore and Garbati, 2011). It was reported that inhibition of NF- $\kappa B$ activation diminished the influx of inflammatory cells and reduce the allergic inflammation (Birrell et al., 2005). These results have suggested the NF- $\kappa \mathrm{B}$ activation is an attractive target for the treatment of allergic inflammatory diseases.

Traditional medicines are commonly used as complementary and alternative therapies for various diseases. Although traditional medicines have long been employed in effectively treating diseases, the pharmacologic mechanisms of them are not completely understood. Zanthoxylum piperitum (ZP) has been used in herbal medicine for various medicinal purposes including stomachic, toothache and anthelmintic problems (Choi et al., 2008; Park et al., 2008). Despite previous studies demonstrating the pharmacological effects of ZP, information on the pharmacologic mechanism of ZP on allergic inflammation including $\mathrm{AD}$ remains limited. The present study was conducted to evaluate the beneficial effects of ZP on 2, 4-dinitrochlorobenzene (DNCB)-induced AD symptoms in mice. Additionally, to find a possible explanation for the anti-allergic mechanisms of $\mathrm{ZP}$, we investigate the effect of $\mathrm{ZP}$ on the expression of inflammatory cytokines as well as activation of NF- $\mathrm{KB}$ in phorbol 12-myristate 13acetate plus calcium ionophore A23187 (PMACI)-stimulated human mast cells (HMC-1).

\section{MATERIALS AND METHODS}

\section{Reagents}

DNCB, PMA, calcium Ionophore A23187, avidin peroxidase (AP), dimethyl sulfoxide (DMSO) and other reagents were purchased from Sigma-Aldrich (St. Louis, MO, USA). Iscove's Modified Dulbecco's Media (IMDM) was procured from Gibco BRL (Grand Island, NY). Fetal bovine serum
(FBS) and enhanced chemiluminescence kit were obtained from Thermo Fisher Scientific Inc. (Somerset, NJ, USA). ELISA kits human TNF- $\alpha /$ IL- 6 and mouse TNF- $\alpha /$ IL- $6 /$ IgE was procured from BD Biosciences (San Diego, CA, USA). NF- $\kappa$ B and histone antibodies (Abs) were purchased from Santa Cruz Biotechnology, Inc. (Santa Cruz, CA).

\section{Preparation of ZP}

Dried roots of $\mathrm{ZP}$ were bought from the Human herb (Gyeongbuk, Korea). ZP (200 g) was pulverized into fine powder and $2 \mathrm{~L}$ of $70 \%$ aqueous ethanol solution was extracted at room temperature for $24 \mathrm{~h}$ and then concentrated under vacuum. The ethanol extract was next filtered, concentrated, and lyophilized (yield: 15.2\%).

\section{Animals}

BALB/c mice (6 weeks, 19 20 g) were purchased from the Hyochang Science (Daegu, Korea). The animals were housed and allowed spontaneous intake of food and water ad libitum. Moreover, the animals were kept under a 12/12-h light/dark cycle at room temperature $24 \pm 2{ }^{\circ} \mathrm{C}$ and humidity $56 \pm 10 \%$. The research was conducted in accordance with the internationally accepted principles for laboratory animal use and care, as described in the Daegu Haany university guidelines.

\section{Induction of AD-like skin lesions}

DNCB (Sigma-Aldrich, St. Louis, MO, USA) was dissolved in vehicle (3:1 acetone:olive oil) and used as a sensitizer for inducing AD-like skin lesions in mice (Chan et al., 2013). The dorsal skin of mice was shaved with depilatory and gauzed a day before sensitization. Mice were randomized divided into 4 groups ( $\mathrm{n}=7 /$ group): vehicle, $\mathrm{DNCB}$, and DNCB plus treatment of ZP $(5 \mathrm{mg} / \mathrm{kg})$ or DNCB plus treatment of ZP $(50 \mathrm{mg} / \mathrm{kg})$. Exposed skin was treated with vehicle or $200 \mu \mathrm{L}$ of a $1 \%$ DNCB for 4 days. After sensitization, the dorsal skin was challenged with a $0.5 \% \mathrm{DNCB}$ $(200 \mu \mathrm{L})$ solution three times per week. This procedure was repeated for 3 weeks and ZP was orally administrated every day for 2 weeks. 


\section{Evaluation of skin dermatitis severity}

The severity of dermatitis was evaluated according to the Eczema Area and Severity Index scoring system: 0, no symptoms; 1 , mild symptoms; 2 , moderate symptoms; and 3 , severe symptoms. The sum of the individual scores was defined as the dermatitis score for erythema/haemorrhage, edema, excoriation/erosion and scaling/dryness (Lee et al., 2010).

\section{Histamine assay}

Blood samples of mice were collected, and serum was separated by centrifugation at $4,000 \mathrm{xg}$ for $20 \mathrm{~min}$ at $4{ }^{\circ} \mathrm{C}$. Histamine concentration in the serum was measured using a specialized ELISA kit according to the manufacturer's instructions (Neogen, Lexington, USA).

\section{Cell culture}

HMC-1 was maintained in IMDM containing with $100 \mathrm{IU}$ $/ \mathrm{mL}$ penicillin, $100 \mu \mathrm{g} / \mathrm{mL}$ streptomycin, and $10 \% \mathrm{FBS}$ at $37^{\circ} \mathrm{C}$ in $5 \% \mathrm{CO}_{2}$ atmosphere at $95 \%$ humidity. HMC-1 was stimulated with of PMA $(50 \mathrm{nM})$ plus A23187 $(1 \mu \mathrm{g} / \mathrm{mL})$.

\section{MTT assay}

To investigate cell viability by ZP, the MTT colorimetric assay was performed. Briefly, cells were incubated with ZP $(0.05,0.5$ and $1 \mathrm{mg} / \mathrm{mL})$ for $12 \mathrm{~h}$ and $50 \mu \mathrm{L}$ of MTT $(5 \mathrm{mg} /$ $\mathrm{mL}$ ) solution was subsequently added and was incubated for $4 \mathrm{~h}$. Then, the crystallized formazan was dissolved in DMSO and the absorbance of plate was read at $540 \mathrm{~nm}$.

\section{Cytokine assay}

The level of TNF- $\alpha$ and IL- 6 was measured by modification of an enzyme-linked immunosorbent assay (ELISA) as previously described (Kim et al., 2010). Briefly, 96-well plates were coated with monoclonal Abs and incubated overnight at $4{ }^{\circ} \mathrm{C}$. After additional washes, sample or standard solution of TNF- $\alpha$ and IL- 6 were added and incubated for $2 \mathrm{~h}$. Plates were next exposed to biotinylated Abs was added and incubated for $2 \mathrm{~h}$. After washing the plates, AP and ABTS substrate containing $\mathrm{H}_{2} \mathrm{O}_{2}$ was sequentially added. Color development was evaluated at $405 \mathrm{~nm}$ by a microplate reader (Molecular Devices, Sunnyvale, CA, USA).

\section{Western blot analysis}

Nuclear extracts were prepared by NE-PER Nuclear and Cytoplasmic Extraction Reagents (Pierce Thermo Scientific, Rockford, USA). After bicinchoninic acid protein quantification, the supernatant was mixed with a sample buffer, separated by gel electrophoresis, and transferred to membranes. The membranes were then blocked with 5\% skimmed milk and subsequently reacted with primary Abs. After washing, membranes were then incubated with secondary Abs for $1 \mathrm{~h}$. After washing with $0.1 \%$ PBST, protein bands were visualized using an ECL detection system.

\section{Luciferase reporter gene assay}

Cells were transiently transfected with NF- $\kappa B-l u c$ DNA and refreshed with completed media. The transfected cells were seeded in 6 plates overnight and treated with ZP before PMACI stimulation for another $2 \mathrm{~h}$. Luciferase activity was determined using a Dual-Glo luciferase assay system kit (Promega, Madison, Wisconsin, USA) following the manufacturer's protocols.

\section{Statistical analysis}

Results are shown as the mean \pm S.D and each experiment was completed at least three times. The statistical results were performed using an independent $t$-test and ANOVA with a Tukey post hoc test. $P<0.05$ was considered significant.

\section{RESULTS}

\section{Effect of ZP on AD symptoms in DNCB-induced AD- like skin lesions}

To evaluate the therapeutic effects of $\mathrm{ZP}$ on $\mathrm{AD}$ symptoms, we used a mouse model of DNCB-induced AD. As shown in Fig. 1A, oral administration of ZP (5 mg/ $\mathrm{kg}$ and $50 \mathrm{mg} /$ $\mathrm{kg}$ ) improved DNCB-induced the AD symptoms, such as erythema, edema and dryness. Moreover, we confirmed that the skin severity scores in the $\mathrm{ZP}$ treatment group were significantly lower than those in the DNCB-treated group (Fig. 1B). These results demonstrated that ZP possibly may 
A

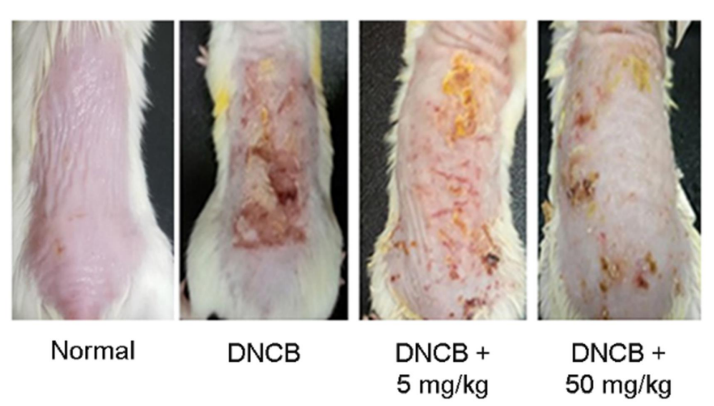

B

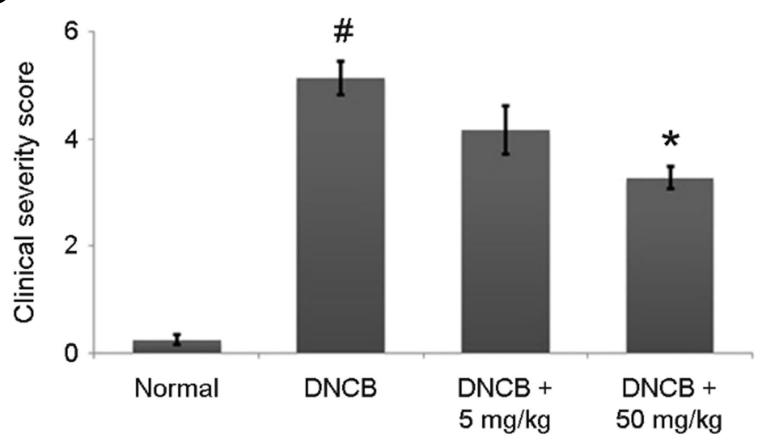

Fig. 1. Effect of ZP on DNCB-induced AD-like skin lesions in mice. (A) Clinical features of AD-like skin lesions. (B) Skin severity score is represented. Values are presented as mean \pm SD of independent experiments $\left({ }^{\sharp} P<0.05\right.$ versus vehicle control group, ${ }^{*} P<$ 0.05 ; versus DNCB- treated group).

have therapeutic activity by diminishing the clinical symptoms of $\mathrm{AD}$.

Effect of ZP on histamine and IgE serum levels in DNCB-induced AD mice

It has been reported that serum levels of histamine and $\mathrm{IgE}$ are increased in $\mathrm{AD}$ patients and have been used as diagnostic tools and therapeutic targets (Gomez, 2019). Therefore, we investigated the inhibitory effects of ZP on serum histamine and IgE levels using ELISA. As shown in Fig. 2A and B, application of DNCB to mice resulted in increased levels of histamine and $\operatorname{IgE}$ in the serum. However, treatment with ZP reduced the histamine and $\mathrm{IgE}$ levels in the serum. The inhibition rates of histamine and IgE by ZP $(50 \mathrm{mg} / \mathrm{kg}$ ) were approximately $31.2 \%$ and $25.9 \%$, respectively $(P<0.05)$. From this, we suggested that ZP exerts an anti-atopic effect by suppression of histamine and IgE serum levels in mice.

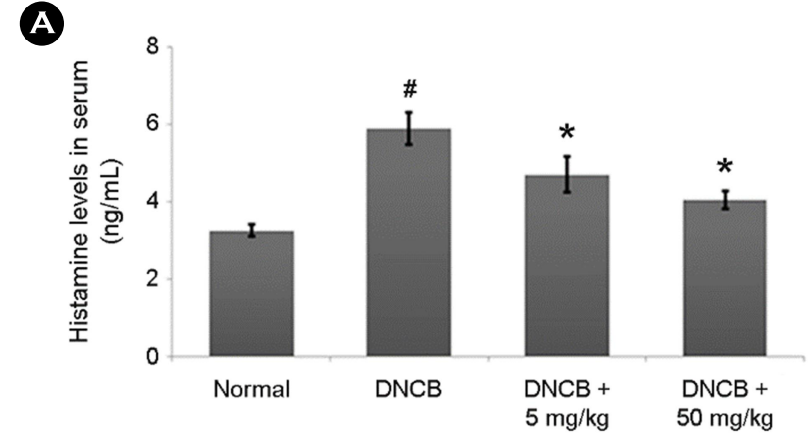

B

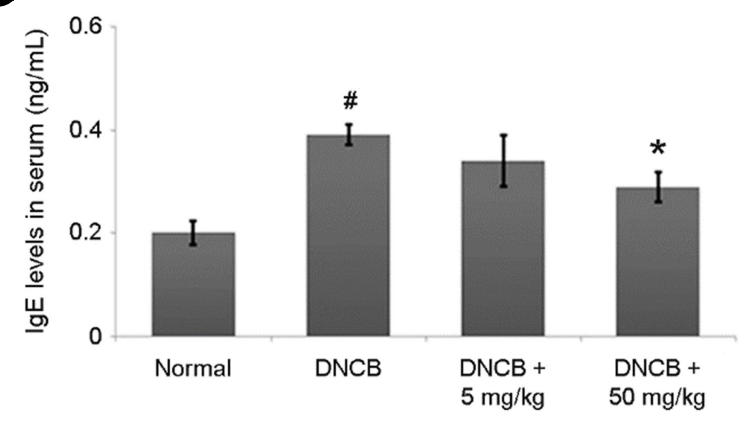

Fig. 2. Effects of ZP on histamine and IgE serum levels in DNCBinduced AD mice. (A and B) Blood samples in DNCB-induced $\mathrm{AD}$ mice were collected and then serum level of histamine and $\mathrm{IgE}$ was measured using ELISA assay kit assay according to the manufacturer's protocols. Values are presented as mean \pm SD of independent experiments $\left({ }^{\#} P<0.05\right.$ versus vehicle control group, ${ }^{*} P<$ 0.05 ; versus DNCB- treated group)

\section{Effect of ZP on inflammatory cytokine levels in AD-like} skin lesions and stimulated HMC-1 cells

Suppression of inflammatory cytokine levels is one of the most widely accepted treatment strategies for allergic inflammation including AD (Furue and Kadono, 2017). Thus, we examined the inhibitory effect of ZP on TNF- $\alpha$ and IL-6 levels in the AD-like skin lesion. At the end of the experiment, dorsal skin lesions were homogenized, and ELISA was performed. The results showed that the levels of TNF- $\alpha$ and IL- 6 were significantly increased in skin tissues from DNCB-treated mice compared to that of control. However, administration of ZP decreased the DNCB-induced increased in TNF- $\alpha$ and IL- 6 levels. The inhibition rates of TNF- $\alpha$ and IL- 6 by ZP ( $50 \mathrm{mg} / \mathrm{kg}$ ) were approximately $29.6 \%$ and $30.1 \%$, respectively (Fig. 3A).

To investigate the anti-inflammatory activity of $\mathrm{ZP}$, the human mast cell line, HMC-1, was employed in this study. 
A
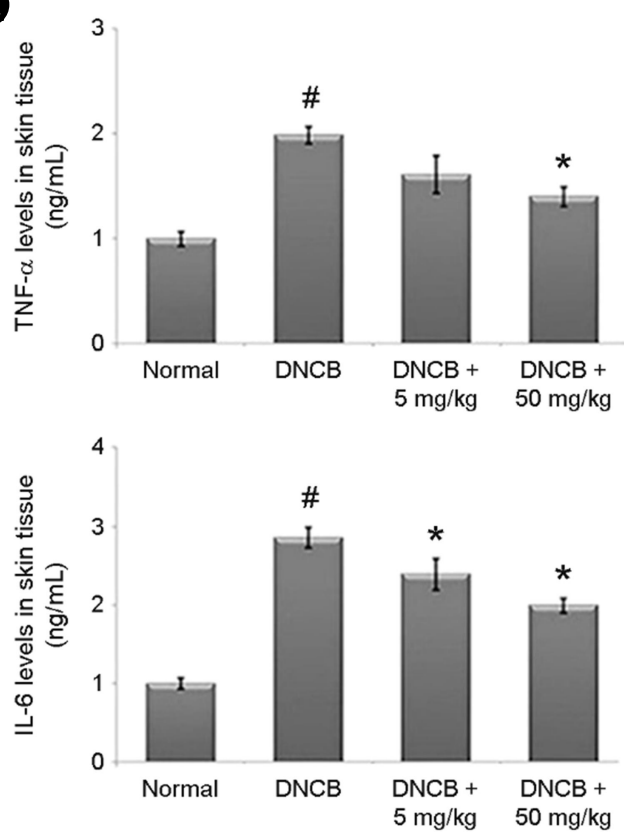

B

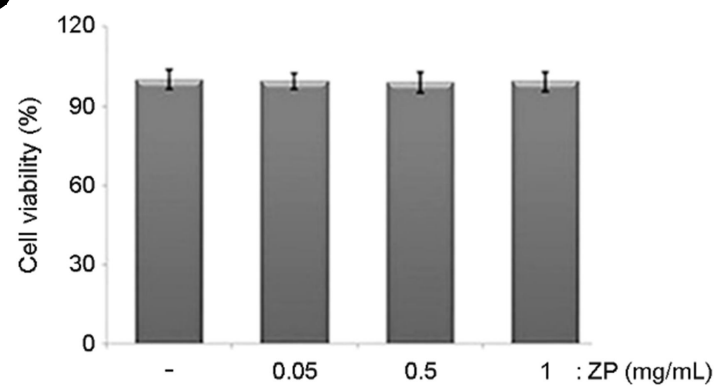

C
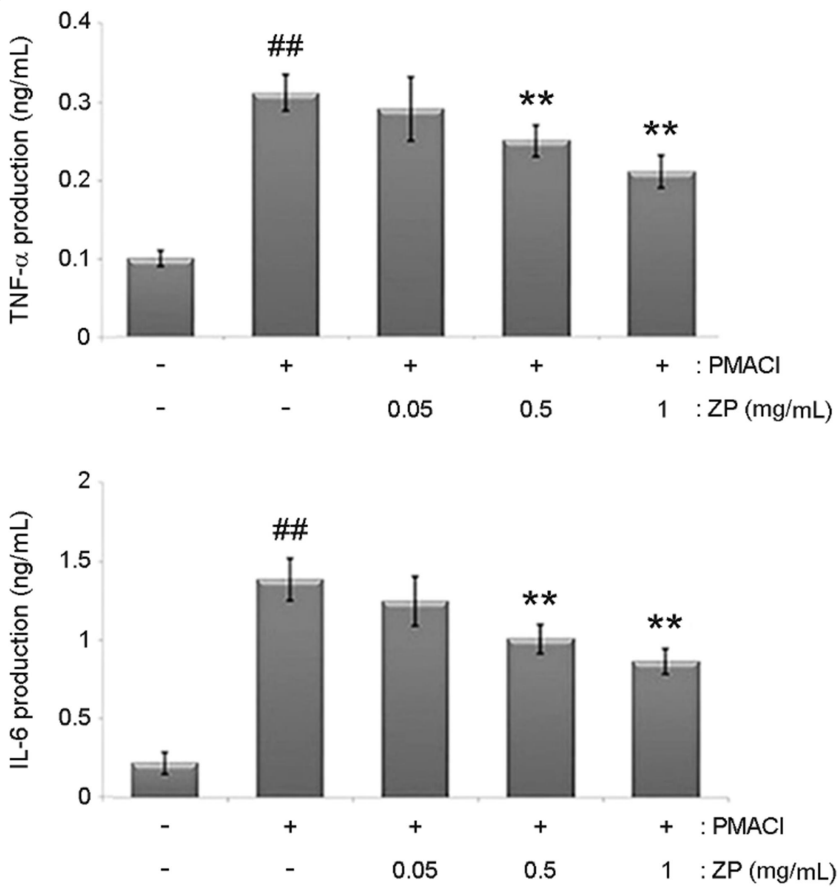

Fig. 3. Effects of ZP on inflammatory cytokines levels in AD-like skin lesion and stimulated HMC-1 cells. (A) At the end of experiment, dorsal skin lesions were cut out and homogenized. The level of TNF- $\alpha$ and IL- 6 in the indicated groups was measured via ELISA assay according to the manufacturer's protocols. (B) Cells were pretreated with ZP $(0.05,0.5$ and $1 \mathrm{mg} / \mathrm{mL})$ for $12 \mathrm{~h}$. Cell viability was analyzed by MTT assay. (C) Cells were pretreated with or without $\mathrm{ZP}(0.05,0.5$ and $1 \mathrm{mg} / \mathrm{mL})$ for 2 h prior to stimulation with PMA (50 $\mathrm{nM})$ plus A23187 $(1 \mu \mathrm{g} / \mathrm{mL})$ for $8 \mathrm{~h}$. The levels of TNF- $\alpha$ and IL-6 in the indicated groups were measured via ELISA method. The results are presented as mean $\pm \mathrm{SD}\left({ }^{\#} P<0.05\right.$ vs. vehicle control mice group, ${ }^{*} P<0.05$ vs. DNCB- treated mice group, ${ }^{\#} P<0.05$ vs. control, ${ }^{* *} P<0.05$ vs PMACI alone).

First, the cytotoxic effects of ZP were evaluated after treatment with various concentrations of $\mathrm{ZP}$ for $12 \mathrm{~h}$ using an MTT assay. No cell cytotoxicity by ZP was observed (Fig. 3B). Next, we evaluated the inflammatory effects of $\mathrm{ZP}$ on TNF- $\alpha$ and IL-6 production in PMACI-stimulated HMC-1 cells. Cells were pretreated with or without ZP $(0.05,0.5$ and $1 \mathrm{mg} / \mathrm{mL}$ ) for $2 \mathrm{~h}$ prior to stimulation with PMACI for $8 \mathrm{~h}$. As shown in Fig. 3C, PMACI alone markedly induced the secretion o TNF- $\alpha$ and IL- 6 compared with the untreated control. However, pretreatment with ZP $(0.05,0.5$ and $1 \mathrm{mg}$ /
$\mathrm{mL}$ ) suppressed TNF- $\alpha$, and IL-6 production in PMACIstimulated HMC-1cells in a dose-dependent manner. The maximal inhibition rates of TNF- $\alpha$ and IL- 6 secretion by $\mathrm{ZP}(1 \mathrm{mg} / \mathrm{mL})$ were approximately $32.2 \%(P<0.05)$ and $37.4 \%(P<0.05)$, respectively. These results demonstrated that ZP exerts anti-inflammatory effects via the inhibition of inflammatory cytokine levels. 
A

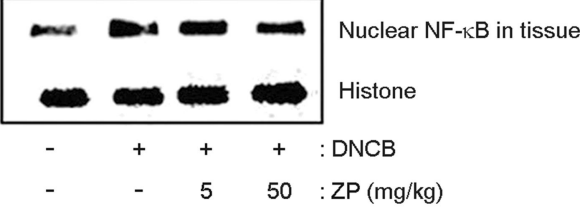

B

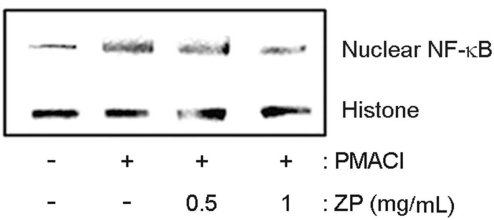

(D)

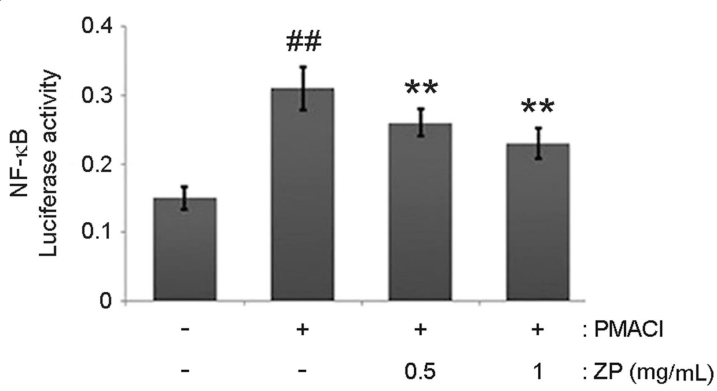

C
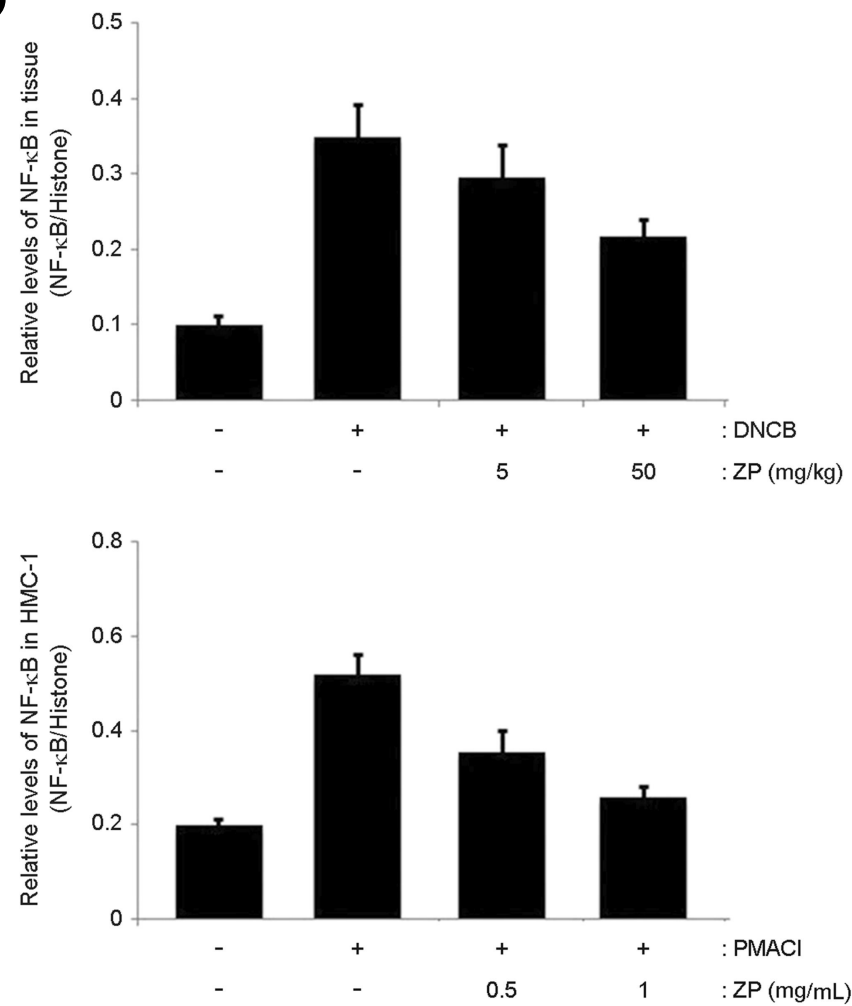

Fig. 4. Effect of ZP on NF-אB activation in AD-like skin lesion stimulated HMC-1 cells. (A) Nuclear extracts from skin tissue were prepared and the NF- $\mathrm{KB}$ levels in nucleus measured via western blot analysis. (B) Cells were pretreated with or without ZP for $2 \mathrm{~h}$ prior to stimulation with PMA $(50 \mathrm{nM})$ plus A23187 $(1 \mu \mathrm{g} / \mathrm{mL})$ for $2 \mathrm{~h}$. The level of NF- $\mathrm{kB}$ in nucleus was evaluated for RelA/p65 via Western blot analysis. (C) The relative levels of nucleus NF- $\mathrm{KB}$ (in AD-like skin lesion and mast cells) were represented. (D) Luciferase activity was determined using a luciferase assay system kit following the manufacturer's instructions. All results are expressed as the means \pm SD ( ${ }^{\sharp} P<0.05$ vs. vehicle control mice group, ${ }^{*} P<0.05$ vs. DNCB- treated mice group, ${ }^{\#} P<0.05$ vs. control, ${ }^{* *} P<0.05$ vs PMACI alone).

\section{Effect of ZP on NF-кB activation in in AD-like skin} lesions and stimulated HMC-1 cells

As the NF- $\kappa \mathrm{B}$ activation is associated with the inflammatory response, we theorized that the anti-inflammatory mechanism of ZP may be mediated via suppression of NF$\kappa \mathrm{B}$ activation. As activation of $\mathrm{NF}-\kappa \mathrm{B}$ requires the translocation of the NF- $\kappa B$ into nucleus (Nakamura et al., 2002), we evaluated the effects of ZP on the nuclear pool of NF-kB in AD-like skin lesion. As illustrated in Fig. 4A, we confirmed that the enhanced NF- $\mathrm{KB}$ activity in DNCB-induced $\mathrm{AD}$-like skin lesions was down-regulated by treatment with ZP in a dose-dependent manner. Additionally, to determine the molecular mechanism of $\mathrm{ZP}$, we evaluated the regulatory effects of $\mathrm{ZP}$ on PMACI-induced NF- $\mathrm{BB}$ activation. In PMACI-stimulated cells, the levels of NF- $\mathrm{KB}$ in the nucleus were increased, but ZP inhibited these enhanced nuclear levels of NF- $\kappa \mathrm{B}$ in a dose-dependent manner (Fig. 4B). The relative levels of nucleus $\mathrm{NF}-\kappa \mathrm{B}$ (in skin tissue and cells) were represented in Fig. 4C. Moreover, we evaluated the effect of ZP on the promoter activity of NF- $\mathrm{KB}$ using luciferase reporter assay. As illustrated in Fig. 4D, ZP reduced the NF- $\kappa \mathrm{B}$-driven luciferase activity in PMACI-stimulated HMC-1 cells. From this, we demonstrated that the antiinflammatory mechanism of ZP can attributed to the inhibition the activation of NF- $\mathrm{KB}$ in $\mathrm{AD}-$ like skin lesion and mast cells.

\section{DISCUSSION}

Recently, traditional medicines have received revived interest in terms of complementary and alternative therapies 
in various diseases. Although ZP has been widely used as a traditional medicine, the precise mechanisms of the effects of $\mathrm{ZP}$ on allergic inflammation including $\mathrm{AD}$ has yet to be thoroughly elucidated. The findings of this study revealed that $\mathrm{ZP}$ reduced the clinical symptoms along with $\operatorname{IgE}$ and histamine serum levels in a DNCB-induced AD model. Additionally, we demonstrated that the anti-inflammatory effect and mechanism of ZP can attributed to the attenuation of inflammatory cytokine expression and NF- $\mathrm{KB}$ activation in AD-like skin lesion and stimulated HMC-1 cells. This result indicated an important molecular mechanism by which $\mathrm{ZP}$ ameliorates the allergic inflammatory reaction.

$\mathrm{AD}$ is a chronic inflammatory skin disease associated with pruritic, swelling and skin redness and affects the quality of life of patients (David et al., 2017). The clinical features of $\mathrm{AD}$ are infiltration of immune cells, epidermal hyperplasia, elevated serum histamine and IgE levels and increased inflammatory cytokines (Waldman et al., 2018). It has been reported that the pathogenesis of $\mathrm{AD}$ is thought to result from a multifactorial interaction of genetic, immune, and environmental factors. Generally, certain drugs including steroid, antihistamine and immunosuppressant are available for the treatment of $\mathrm{AD}$. However, it cannot be administered longterm because of their deleterious side effects (Das and Panda, 2017). Thus, natural products have gained attention for relief of AD (Shiohara et al., 2004). Firstly, we tested the antiatopic effects of $\mathrm{ZP}$ against DNCB-induced experimental $\mathrm{AD}$ progression in this study. Various biomarkers are employed to measure the severity of clinical symptoms of experimental AD. In particular, serum IgE and histamine levels are considered one of the crucial markers of $\mathrm{AD}$ as patients with it exhibit significantly increased serum $\operatorname{IgE}$ and histamine levels compared with healthy patients (Furue et al., 2017). In present study, we found that topical treatment of ZP significantly reduced $\mathrm{AD}$ symptoms such as erythema, edema and dryness in mice. Additionally, we observed that ZP suppressed DNCB-induced IgE and histamine levels in the serum. These results demonstrated that ZP possibly may have therapeutic activity by diminishing the clinical symptoms of $\mathrm{AD}$ along with serum $\mathrm{IgE}$ and histamine levels.

Several researchers have shown that inflammatory cytokines are related to the development of AD. Inflammatory cytokines highly express in activated mast cells and $\mathrm{AD}$ skin lesion, which induce allergic inflammation (Lim et al., 2018). It has also been reported that TNF- $\alpha$ and IL- 6 levels are elevated in patients with $\mathrm{AD}$ and plays an integral role in $\mathrm{AD}$ pathogenesis (Fedenko et al., 2011). These results indicate that new biological therapies for $\mathrm{AD}$ should focus on suppression the inflammatory cytokines. Additionally, we examined the regulatory effect of $\mathrm{ZP}$ on intracellular signaling molecules involved in PMACI signaling pathways in HMC1. Activated mast cells release an array of cytokines and chemokines with the potential to cause skin inflammation (Voisin and Chiu., 2018). These reports suggest that downregulation of inflammatory cytokine from mast cells is necessary to successfully modulate AD. In this study, we showed that the levels of TNF- $\alpha$ and IL- 6 were increased in ADlike skin lesions compared to those in controls and that ZP reduced these increased TNF- $\alpha$ and IL-6 levels in AD-like skin lesions. In addition, we demonstrated that $\mathrm{ZP}$ attenuated the release of TNF- $\alpha$ and IL-6 in PMACI-simulated HMC1 cells. The inhibition rates of TNF- $\alpha$ and IL- 6 by ZP (1 mg/ $\mathrm{mL}$ ) were approximately $32.2 \%$ and $37.4 \%$, respectively. These results suggest that ZP exerts an anti-inflammatory effect by suppressing of TNF- $\alpha$ and IL-6 release from mast cells.

$\mathrm{NF}-\kappa \mathrm{B}$ regulates the transcription of numerous genes involved in allergic inflammation (Gilmore and Garbati, 2011). In inactive state (under normal condition), complexes of NF$\kappa \mathrm{B} / \mathrm{I} \kappa \mathrm{B}$ is sequestered in the cytoplasm. During the inflammatory process, IאB kinase (IKK) complex phosphorylate and degrade the I $\kappa \mathrm{B}$ protein (Huber et al., 2002). As a result, free NF- $\mathrm{KB}$ is translocate into the nucleus where it can combine the promoter of target genes and activate various inflammatory factors. Based on these results, suppression of NF$\kappa \mathrm{B}$ activation was identified as an anti-inflammatory strategy. Therefore, to identify the anti-inflammatory mechanism of $\mathrm{ZP}$, we assessed whether ZP could suppress the activation of NF- $\kappa$ B. The results demonstrate that ZP inhibited NF$\kappa \mathrm{B}$ translocation into the nucleus in $\mathrm{AD}$-like skin lesion and stimulated HMC-1 cells. We hypothesized that ZP exerts anti-atopic effects via the inhibition of NF- $\mathrm{KB}$ activation. Although ZP attenuated NF- $\kappa B$ activation, the effect of ZP on another pathway including MAPK-signaling was not 
elucidated. Therefore, further studies are necessary to clarify the role of ZP on the other pathway in mast-cell mediated skin inflammation.

In conclusion, the present study demonstrated ZP might relieve AD clinical symptoms as well as IgE and histamine serum levels in a DNCB-induced AD model. Additionally, we demonstrated that the anti-atopic activity of ZP can attributed to the inhibition the expression of inflammatory cytokine and activation of NF- $\mathrm{BB}$ in $\mathrm{AD}$-like skin lesion and stimulated mast cells. These results provide experimental evidence that ZP may be useful candidate for treating inflammatory skin diseases including AD.

\section{ACKNOWLEDGEMENT}

This research was supported by Basic Science Research Program through the National Research Foundation of Korea (NRF) funded by the Ministry of Education (NRF -2017R1D1A1B03031186).

\section{CONFLICT OF INTEREST}

The authors declare that there are no conflicts of interest.

\section{REFERENCES}

Berke R, Singh A, Guralnick M. Atopic dermatitis: an overview. American Family Physician. 2012. 86: 35-42.

Birrell MA, Hardaker E, Wong S, McCluskie K, Catley M, De AJ, Newton R, Haj-Yahia S, Pun KT, Watts CJ, Shaw RJ, Savage TJ, Belvisi MG. Ikappa-B kinase-2 inhibitor blocks inflammation in human airway smooth muscle and a rat model of asthma. American Journal of Respiratory and Critical Care Medicine. 2005. 172: 962-971.

Chan CC, Liou CJ, Xu PY, Shen JJ, Kuo ML, Len WB, Chang LE, Huang WC. Effect of dehydroepiandrosterone on atopic dermatitis-like skin lesions induced by 1-chloro-2,4-dinitrobenzene in mouse. Journal of Dermatological Science. 2013. 72: 149-157.

Choi SI, Chang KM, Lee YS, Kim GH. Antibacterial activity of essential oils from Zanthoxylum piperitum A.P. DC. and Zanthoxylum schinifolium. Food Science and Biotechnology. 2008. 17: 195-198.

Das A, Panda S. Use of Topical Corticosteroids in Dermatology: An Evidence-based Approach. Indian Journal of Dermatology.
2017. 62: 237-250.

David Boothe W, Tarbox JA, Tarbox MB. Atopic Dermatitis: Pathophysiology. Advances in Experimental Medicine and Biology. 2017. 1027: 21-37.

Fedenko ES, Elisyutina OG, Filimonova TM, Boldyreva MN, Burmenskaya OV, Rebrova OY, Yarilin AA, Khaitov RM. Cytokine gene expression in the skin and peripheral blood of atopic dermatitis patients and healthy individuals. Self Nonself. 2011. 2: 120-124.

Furue M, Kadono T. "Inflammatory skin march" in atopic dermatitis and psoriasis. Inflammation Research. 2017. 66: 833-842.

Furue M, Chiba T, Tsuji G, Ulzii D, Kido-Nakahara M, Nakahara T, Kadono T. Atopic dermatitis: immune deviation, barrier dysfunction, IgE autoreactivity and new therapies. Allergology International. 2017. 66: 398-403.

Gilmore TD, Garbati MR. Inhibition of NF- $\mathrm{kB}$ signaling as a strategy in disease therapy. Current Topics in Microbiology and Immunology. 2011. 349: 245-263.

Gomez G. Current Strategies to Inhibit High Affinity FceRIMediated Signaling for the Treatment of Allergic Disease. Frontiers in Immunology. 2019. 10: 175-185.

Hawiger J. Innate immunity and inflammation: a transcriptional paradigm. Immunologic Research. 2001. 23: 99-109.

Huber MA, Denk A, Peter RU, Weber L, Kraut N, Wirth T. The IKK-2/Ikappa Balpha /NF-kappa B pathway plays a key role in the regulation of CCR3 and eotaxin-1 in fibroblasts. A critical link to dermatitis in Ikappa Balpha-deficient mice. Journal of Biological Chemistry. 2002. 277: 1268-1275.

Kim SJ, Kim MC, Um JY, Hong SH. The beneficial effect of vanillic acid on ulcerative colitis. Molecules. 2010. 15: 7208 $-7217$.

Lee YS, Han SB, Ham HJ, Park JH, Lee JS, Hwang DY, Jung YS, Yoon DY, Hong JT. IL-32 $\gamma$ suppressed atopic dermatitis through inhibition of miR-205 expression via inactivation of nuclear factor-kappa B. Journal of Allergy and Clinical Immunology. 2020. 146: 156-168.

Lee KS, Jeong ES, Heo SH, Seo JH, Jeong DG, Choi YK. A novel model for human atopic dermatitis: application of repeated DNCB patch in BALB/c mice, in comparison with NC/Nga mice. Laboratory Animal Research. 2010. 26: 95-102.

Lim JM, Lee B, Min JH, Kim EY, Kim JH, Hong S, Kim JJ, Sohn Y, Jung HS. Effect of peiminine on DNCB-induced atopic dermatitis by inhibiting inflammatory cytokine expression in vivo and in vitro. International Immunopharmacology. 2018. 56: 135-142. 
Modena BD, Dazy K, White AA. Emerging concepts: mast cell involvement in allergic diseases. Translational Reserch. 2016. 174: 98-121.

Nakamura H, Aoki M, Tamai K, Oishi M, Ogihara T, Kaneda Y, Morishita R. Prevention and regression of atopic dermatitis by ointment containing NF- $\mathrm{kB}$ decoy oligodeoxynucleotides in NC/Nga atopic mouse model. Gene Therapy. 2002. 9: 1221 -1229 .

Park HS, Jun DY, Fang Z, Woo MH, Kim YH. Antimicrobial activity of seeds of Zanthoxylum piperitum against oral pathogen Streptococcus mutants. Journal of Life Science. 2008. 18: $167-174$.

Shiohara T, Hayakawa J, Mizukawa Y. Animal models for atopic dermatitis: are they relevant to human disease?. Journal of Dermatological Science. 2004. 36: 1-9.

Siraganian RP. Mast cell signal transduction from the high-affinity IgE receptor. Current opinion in immunology. 2003. 15: 639 $-646$.
Trefzer U, Hofmann M, Sterry W, Asadullah K. Cytokine and anticytokine therapy in dermatology. Expert Opinion on Biological Therapy. 2003. 3: 733-743.

Waldman AR, Ahluwalia J, Udkoff J, Borok JF, Eichenfield LF. Atopic Dermatitis. Pediatrics in Review. 2018. 39: 180-193.

Vatti RR, Ali F, Teuber S, Chang C, Gershwin ME. Hypersensitivity reactions to corticosteroids. Clinical Reviews in Allergy and Immunology. 2014. 47: 26-37.

Voisin T, Chiu IM. Molecular link between itch and atopic dermatitis. Proceedings of the National Academy of Sciences of the United States of America. 2018. 115: 12851-12853.

https://doi.org/10.15616/BSL.2020.26.3.192

Cite this article as: Jeong DJ, Kim SJ. Zanthoxylum Piperitum Attenuates the Allergic Inflammation in vivo and in vitro. Biomedical Science Letters. 2020. 26: 192 -200 . 